\title{
アナログ型電力系統シミュレータによる内部型 パラメータ共振の発生の確認抒よび計測技術の検討
}

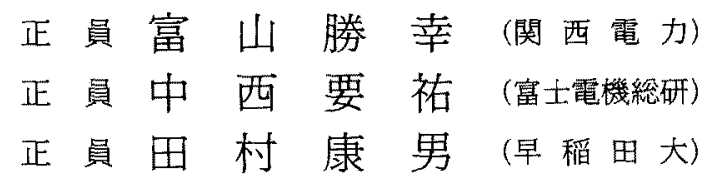

\section{Confirmation of the Auto-Parametric Resonance Phenomena on an Analog-Type Power System Simulator and Promotion of Problem-Oriented Instrumentation Technique}

Katsuyuki Tomiyama, Member (Kansai Electric Power Co., Inc), Yosuke Nakanishi, Member (Fuji Electric Corporate R \& D, Ltd), Yasuo Tamura, Member (Waseda University)

Auto-parametric resonance has not been detected nor observed in a real power system, probably because the problem-oriented instrumentation network is not available today. It has been confirmed by our research group from the viewpoint of theory, digital simulations, and artificial transmission system with rotating machines that the auto-parametric resonance may come out in a power system where certain types of resonance conditions are satisfied as when the initial transient impact such as line opening, generator tripping, and a line-to-ground fault has been applied.

The objective of this paper is to confirm the auto-parametric resonance phenomena on a largescale advanced-type power system simulator (APSA) which features various functions which are very close to those of a real power system, and to promote the instrumentation techniques needed to record and analyze such infrequent phenomena.

キーワード：パラメータ共振, APSA, 多重尺度法, 長時間動特性(LTD), 笴与率行列, 最大エント ロピー法 (MEM)

\section{1.まえがき}

異常現象は一般に構造上，運用上の悪条件を背景と し，これに許容値を超える外乱が組み合わされて発生す るものと考えられる。また近年，電力系統では有効電 力の不均衡による従来の不安定性に加えて, 無効電力 の不均衡による新しいタイプの不安定性を経験するに 至った。新しい現象に遭遇するということはどこか に稀頻度現象が隠れていて，電力系統状態の悪条件性 の進行に伴い，顕在化するものと考えられる。図 1 は 電力系統において，現象と遭遇し確認する際のいろい ろな形態を示したものである(1)。理論化基づく予見
$(A)$ ，発見的事実·連想 $(B)$ に始まって，実系統での 観測, 試験 $(F)$ に終わる。遭遇や確認の筋道は場合 によって異なり，当初発見的事実と考光られていた現 象が理論によって裹づけられたり，現象の存在がディ ジタルシミュレーション $(C)$ にって確認されるこ ともある。専用のシミュレータ $(D)$ や模擬送電系統 (E) は，限られた範囲で実系統と酷似しているので， その結果は説得力があり，ディジタルシミュレーショ ンの結果を追認してくれる。実系統での試験・観測・解 析 $(F)$ に基づく現象確認性現在非常に困難である。 近い将来，常時監視用の計測体制を整備のうえ，系統 現象について知識を蓄積していくことが切望される。 
電力系統のパラメータ共振現象は, 著者らが近年そ の存在の可能性を力説している特異現象で，(i)交流 送電特性の非線形性 $(\sin \theta)$, (ii) 系統のもつダンピ ングの低下，(iii）地絡事故のショックなどが重なり合 って発生する。ある時間断面で求めた線形化常微分方 程式の固有值がすべて左半平面にあっても，その幾つ かが虚軸に近く，かつ共振条件が成立すると，(i)系 統周波数や系統間を行き来する電力の振動が持続し， 系統運用のマージンが減少し, 送電線の利用率が低下 したり，(ii)系統事故や線路開閉などのショックによ り，系統動摇が発生したりする可能性がある(2)。

本論文に述べるパラメー夕共振の確認は, 図1にお ける発見的事実・連想 $(B)$ から出発し, 理論 $(A), テ ゙$ イジタルシミュレーション $(C)$, 模擬送電系統 $(E)$, における現象の確認を経たのち, 専用のアナログ型電 力系統シミュレータ $(D)$ にる検証階段に入ってい る。ここでは $(D)$ として大型電力系統シミュレータ APSA (Advanced Power System Analyzer) を選定 した(3) (9)。これは実系統 $(F)$ に打ける現象確認のた $內 の$, 莀時間現象記録装置扔よび電力系統の常時監視 方式がいまだ不十分な段階にあり，専用シミュレータ (D) に上る解析は有効な手段であると考元るためであ る。さて，パラメータ共振は外部型パラメータ共振と 内部型パラメータ共振に大別できるが，外部型パラメ 一夕共振については, 既に簡略モデルおよび詳細モデ ル (ParkモデルのみとParkモデル + AVR+ $+G_{o v}$ ) を用いてディジタルシシュレーション $(C)$ を行った が，考察対象となる外乱周波数の範囲においては，状 態変数の振幅が描く共振曲線の全貌は大局的に一致し ている。

しかし，第 4 章で示した内部型パラメータ共振の時

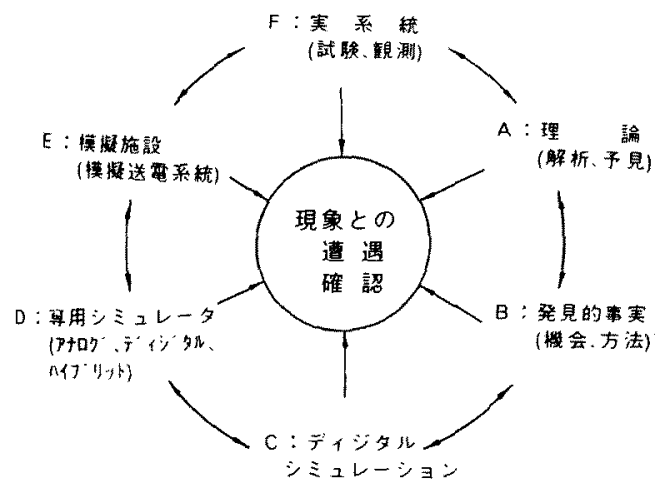

図 1 現象との遭遇と確認

Fig. 1. Encounter with phenomena \& confirmation thereof.
間軸波形は，簡略モデルのそれと詳細モデルのそれ はかなり相異し，しかも詳細モデルの波形はAPSA と酷似していることが判明した。

一方, 電力系統のパラメー夕共振は長時間動特 性 ${ }^{(20)}$ (Long-Term-Dynamics; LTD) の典型的な例 であると考えられるので，ディジタルシミュレーショ ン (C)では， $\tau \max / \tau \min$ が焏めて大きなものの代 表例となり，ディジタルミュレーション $(C)$ を用 いた場合の計算精度の低下, 計算の能率の低下は免れ ない。このような墂境の下では APSAのようなアナ ログシミュレータは，その欠点を解決してくれる可能 性が大であり，また，計測技術の確立を目指し今回の 研究を行った。

\section{2. 電力系統におけるパラメータ共振現象の 分類 ${ }^{(11)(12)}$}

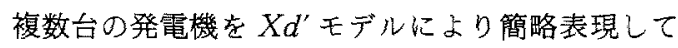
も，大局を把握した共振条件の導出が可能であると考 え，撜動法の一種である Multiple Scales 法（多重尺 度法) ${ }^{(13)(14)}$ の一次近似を用いて共振条件を導出した。 これを表 1 に示す。同表の内部型共振において，共振 条件は異なる 3 モード $p, q, r$ の固有周波数の関係を 表しており， $q=r(=i)$ の場合も含んでいる。すな わち，異なる 2 モード $p ， i$ 間の共振として， $\omega_{p}=$ $2 \omega_{i}$ の共振も意味する。以下に述べるAPSAによる 試験は,この 2 モード間の内部共振現象のケースにつ いて検討したものである。

\section{APSA によるシミュレーション}

パラメー夕共振に対する現象波形の分析手法と、そ の現象確認の手法を確立するため, アナログシミュレ ータによるシミュレーションを行った。このアナログ シミニレータとしては，電力系粒に発生する多様な現 象を極力忠実に再現でき，かつ未経験の系統現象を的 確に予测するために，平成元年より運用されている大 規模高性能系統解析試駼装䈯 (APSA) を選定し $た^{(3)-(19)}$ 。

表 1 電力系統におけるパラメー夕共振の分類

Table 1. Classification of parametric resonance in power systems.

\begin{tabular}{|c|c|}
\hline \$17 & 共振条件 \\
\hline 楾形共振 & $\omega p \div \Omega \tau$ \\
\hline HETEROI & $\omega_{\mathrm{p}}- \pm\left(\Omega_{\mathrm{r}} \pm \Omega_{\mathrm{s}}\right)$ \\
\hline 外部型 HETERO II & $\Omega_{\mathrm{r}} \dot{\sim} \pm\left(\omega_{\mathrm{p}} \pm \omega \mathrm{q}\right)$ \\
\hline 内部型 AUTO & $\omega p \rightarrow \pm(\omega q \pm \omega r)$ \\
\hline
\end{tabular}

wik ; 系統の固有角周波数 $\Omega_{\mathrm{j}}$ : 外乱角周波数 
本シミュレータでは，既に奏系統試験に対する再現 試験を行い(15) (17)，系統現象に対する妥当性を得てい るが, 今回, 本シミュレーションのような系統の非線形 現象に注目した，共振現象の確認実験とその現象波形 の分析を初めて実施し，各種のデータを収集した。

〈3・1〉実験手順 今回解析した系統は図 203 機 9 母線系統(18)である。図中に示した計測情報（各 発電機の $P, \delta)$ は, ワークステーションより選択し, データロガーやアナライジングレコーダに出力した。 また，現象の動摇周期を考慮し，サンプル周期 $\Delta t$ は $50 \mathrm{~ms}(f$ sample $=20 \mathrm{~Hz})$ とした。

試験前の検討として，Xd'モデルによるディジタ ルシミュレーションとAPSAに招ける外部共振実験 により，内部共振実験の共振周波数の手掛かりを得る

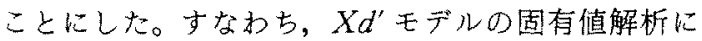
よって求めた固有周波数のなかで，二つの固有周波数 が，内部共振の共振条件(表 1)を満たすように，パラ メー夕(単位慣性定数)を調整した。

〈3・2〉波形分析手法計測波形に対するパラメ 一夕共振現象の把暒を行うために，その波形に含まれ るモード周波数・減衰を分析，あるいは雑音除去など を行う必要がある。また，この技術は実系統での現象 解析にとっても重要な技術であるといえる。

今回適用した波形分析手法は，FFTによりモード 周波数を試験中に確認し，試験後にFFT の空枠の時 間方向への移動（移動 FFT）を行い，その減衰状態 の数值検討を行うことにした。FFTは，時間領域の 波形を高速フーリエ変換し，各周波数成分のスペクト 儿密度を求めるものであり，計測波形の振動モードを 確認できるが，その解析管枠を時間軸方向に逐次移動 させ，各周波数成分の時間的変化をも調べることがで きる。

一方，共振状態で発生する振幅のビート的な現象を 解釈するためには，周波数成分が非常に近寄っている ため, スペクトル分解能が優れている必要があり、こ のため今回は最大エントロピー法(19)(20)を適用した。 最大エントロピー法（以下，MEM）注，時間領域の 波形の自己相関関数を求め，これをフーリエ変換する もので，上記のFFTとはWiener-Khintchine(WK）の公式により図 3 の関係で結ばれている。また, MEMによるスペクトル解析は, 確率過程に自己回㷌 式をあてはめることに等しく，このため予測誤差フィ ルタの項数の決定法に問題があるものの，非常に精度 の高いスペクトル周波数分解能を与える。今回用いた スペクトル解析の設定は以下のと放りである。

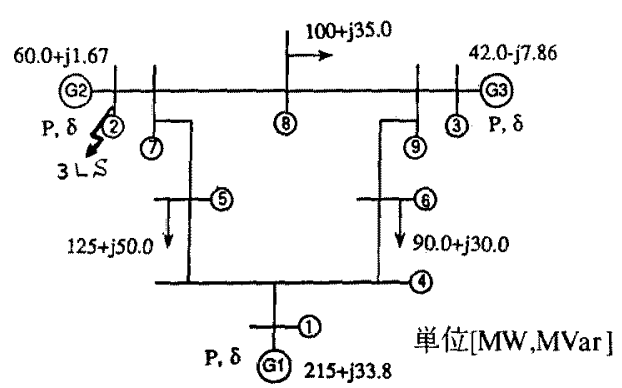

図 $2 A \& F 3$ 機系の系統図および潮流 Fig. 2. $A \& \&$ 3-machine-system and load flow.

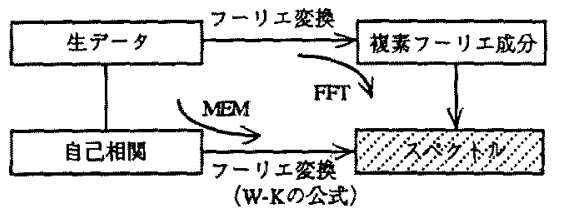

図 3 FFT と MEM の関係

Fig. 3. Relationship between FFT \& MEM.

$$
\begin{aligned}
& \text { サンプリングタイム } \Delta t: 0.05 \mathrm{~s} \\
& \text { データ数 } N: 512 \text { 個 }
\end{aligned}
$$

空枠 $T: 25.6 \mathrm{~s}(=\Delta t \times N)$

Nyquist 周波数 $f_{N}: 10 \mathrm{~Hz}[=1 /(2 \Delta t)]$

基本周波数幅 $\Delta f: 0.039 \mathrm{~Hz}(=1 / T)$

葖枠移動幅： $1 \mathrm{~s}$

\section{APSA の実験とディジタルシミュレー ションとの比較}

本章では，APSAの測定データ拉よびディジタル シミュレーション(Parkモデル㧍よびX $X d^{\prime}$ モデル)の 三者に対して，固有周波数抢よび時間軸波形を比較し， 更に，内部型パラメー夕共振の発生の確認を行う。

$\langle 4 \cdot 1\rangle$ 実験ヶース 表 2 に, 対象とする二つの 実験ケースについて記す。両ケースは，制動巻線の有 無および事故時間が異なっている。

実験に先立ち，拉よその共振条件を成立させるため に，あらかじめ簡略モデル（Xd'モデル）による固 有周波数が 1:2 の関係になるように $H_{2}$ を 6.40 加ら 7.5 に調整した。

両ケースの特徵を把握するために，固有値扔よび奇 与率について調べる。発電機をPark の7次式で表現 した場合, 固有値は, 7 (次) $\times 3$ (機) $=21$ 個存在する。

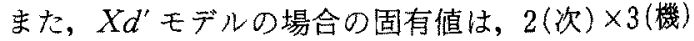


表 2 奉験ケース

Table 2. Cases of experiment.

\begin{tabular}{|c|c|c|c|c|c|}
\hline \multirow{2}{*}{$\begin{array}{l}\text { Case No. } \\
\text { Case } 1 \\
\end{array}$} & \multirow{2}{*}{$\begin{array}{c}\begin{array}{c}\text { 事故時間 } \\
\text { [sec] }\end{array} \\
0.208\end{array}$} & \multirow{2}{*}{$\begin{array}{c}\text { 制動 } \\
\text { 巻線 } \\
\text { 無 }\end{array}$} & \multirow{2}{*}{\begin{tabular}{|c} 
惯性定数 \\
$\mathrm{H}$
\end{tabular}} & \multicolumn{2}{|c|}{ 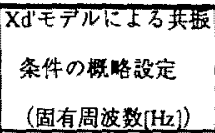 } \\
\hline & & & & 0.94 & 1.88 \\
\hline Case 2 & 0.333 & 有 & 17.5 & 0.94 & 1.88 \\
\hline
\end{tabular}

表 3 Case 1 の優勢な複素固有値 Table 3. Dominant eigenvalues in Case 1.

\begin{tabular}{|c|c|c|c|c|}
\hline 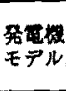 & $モ ー F$ & $\begin{array}{l}\text { 固有価 } \\
\text { 実部 }\end{array}$ & $\begin{array}{c}\text { 直有值 } \\
\text { 虚部 }\end{array}$ & 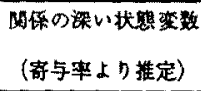 \\
\hline \multirow{2}{*}{ Park } & No.1 & -0.0712 & \pm 4.5835 & $\delta_{1}, \delta_{1}, \delta_{2}, \delta_{2}$ \\
\hline & No.2 & -0.1662 & \pm 8.7714 & $\delta, \delta$, \\
\hline \multirow{2}{*}{$\mathrm{Xu}$} & No.1 & 0.0000 & \pm 5.8951 & $\delta_{1}, \delta_{1}, \delta_{2}, \delta_{2}$ \\
\hline & No. 2 & 0.0000 & \pm 11.7740 & $\delta_{3}, \delta_{2}$ \\
\hline
\end{tabular}

表 4 Case 2 の優勢な複素固有值 Table 4. Dominant eigenvalues in Case 2.

\begin{tabular}{|c|c|c|c|c|}
\hline 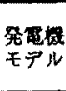 & $z-r$ & $\begin{array}{l}\text { 固有檤 } \\
\text { 実部 }\end{array}$ & $\begin{array}{l}\text { 固有傅 } \\
\text { 虚部 }\end{array}$ & 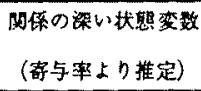 \\
\hline \multirow{2}{*}{ Park } & No.1 & -0.1985 & \pm 4.6000 & $\delta_{1}, \delta_{1}, \delta_{2}, \delta_{2}$ \\
\hline & No. 2 & -0.6204 & \pm 8.8705 & $\delta_{3}, \dot{\delta}_{3}$ \\
\hline \multirow{2}{*}{$\mathrm{X} \mathbb{A}^{*}$} & No.1 & -0.0847 & \pm 5.8937 & $\delta_{1}, \dot{\delta}_{1}, \delta_{2}, \delta_{2}$ \\
\hline & No.2 & -0.4882 & \pm 11.7624 & $\delta, \dot{\delta}$, \\
\hline
\end{tabular}

注 1) 固有値の単位は $(\mathrm{rad} / \mathrm{s})$

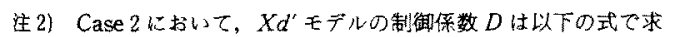
め) (21)。

$D=\left(X d^{\prime}-X d^{\prime \prime}\right) T d o^{\prime \prime} /\left(X d^{\prime}+0.1\right)^{2} \sin ^{2} 0.349$ この式より, $+\left(X q-X q^{\prime \prime}\right) T q o /(X q+0.1) \cos ^{2} 0.349$

$D_{1}=0.00827, D_{2}=0.02767, D_{2}=0.01983$ と求め的地。

また, Case IのXd゙モテルにおいては、制動巻線なしという状 態を、制御係数 $D$ 需とすることによって模擬したため, 固有值 の実部奶零となっている。

=6個となる。3機系の場合，どちらのモデルにせよ 発電機の慣性に関係の深い優勢な複素固有値は 2 組存 在するが, Case 1 およびCase 2 のそれぞれについ て, これらの複素固有値を表 3 および表 4 に示す。各 固有值について, 寄与率を参考に関係の深い状態变数 を右側に記した。

なお，固有値はEISPACK Ver. 8.2 を用いて計算 した。表 3 および表 4 より，発電機 3 とモードNo.2 の関連が深いことが寄与率により推定できる。

〈4・2〉出力 $P$ の時間軸波形図 4 お よび図 5 に, Case 1 および Case 2 の発電機出力 $P$ の時間軸 波形を示す。ここで，各列はそれぞれ
(I) APSAの計測波形

（II）Park モデルを用いたディジタル計算の波形

（III） Xd' モデルを用いたディジタル計算の波形 に対応寸る。また, 各々の列に拈いて，(a)〜(c)図 は発電機出力 $P_{1}, P_{2}, P_{3}$ をそれぞれ示す。ここで, 数 值積分手法注 Runge-Kutta 法 (4 次) を用い, 時間 刻み幅 $\Delta t=0.3 \mathrm{~ms}$ とした。

図 4 肟よび図 5 を見ると，APSAの計測波形と Parkモデルによる計算結果は, 前者に雑音による高 周波成分が含まれていることと，事故前から既に動摇 が諗められたことを考慮すれば同様な波形を得てい る。また, APSA, Park モデルの両者において, 出 力 $P_{3}$ の振幅が最初の 3 秒間程度增大し, その後減少 している点は，非線形システムの特徴を示しているよ うに思われる。

一方， $X d^{\prime}$ モデルの時間軸波形は, APSA および Park モデルの波形とはかなり異なったものとなって いる。すなわち, ParkモデルのP P の波形は APSA のそれと似ていて, 初期振幅の增大扔よび減少が図に

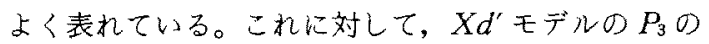
波形はこのような增大杍よび減少が見られない。

〈4・3〉モード領域の波形および弚の隇衰定数に 耆目したエネルギー授受の確認 (Park モデル)

図 6 および図 $7 R$, ディジタルシミュレーション (Parkモデル) に扔けるCase 1 抢よびCase 2 の各 状態変数をモード変換した值のうち, 優勢なモードで ある(a)モードNo.1および(b)モードNo.2の時間 軸波形を示し，それぞれのモードのエンベロープの減 衰を(c)，(d)図に示す。

（1）波形の観察 図6 扔よび図7を見ると，モ 一ドNo.2の時間軸波形に扔いて, 振幅が最初のうち は增大し, 次いで咸少していることがわかる。表 3 お よび表 4 より，モードNo. 2 は発電機 3 と関連が深い モードであることが寄与率により推定されるが，これ は, 発電機出力 $P_{3}$ と, モードNo.2の波形がよく似 た傾向を示していることからも確かめられる。これは まさに寄与率の示していることと矛盾しない。

（2）エネルギー授受の確認系統にダンピング が存在し，それによる隇衰効果がエネルギ一授受によ る振幅の增加を一部相殺してしまう場合には，モード 波形を直接観察するだけではエネルギー授受の確実な 判定はできない。そのため，エネルギーの移動方向が 変わったとき，両モードの減衰定数が変化するである うという考光方に基づき，エネルギ一授受の有無を判 定した。この方法は, モード波形を求め得るディジタ ル計算に対してのみ適用できここではPark モデル 

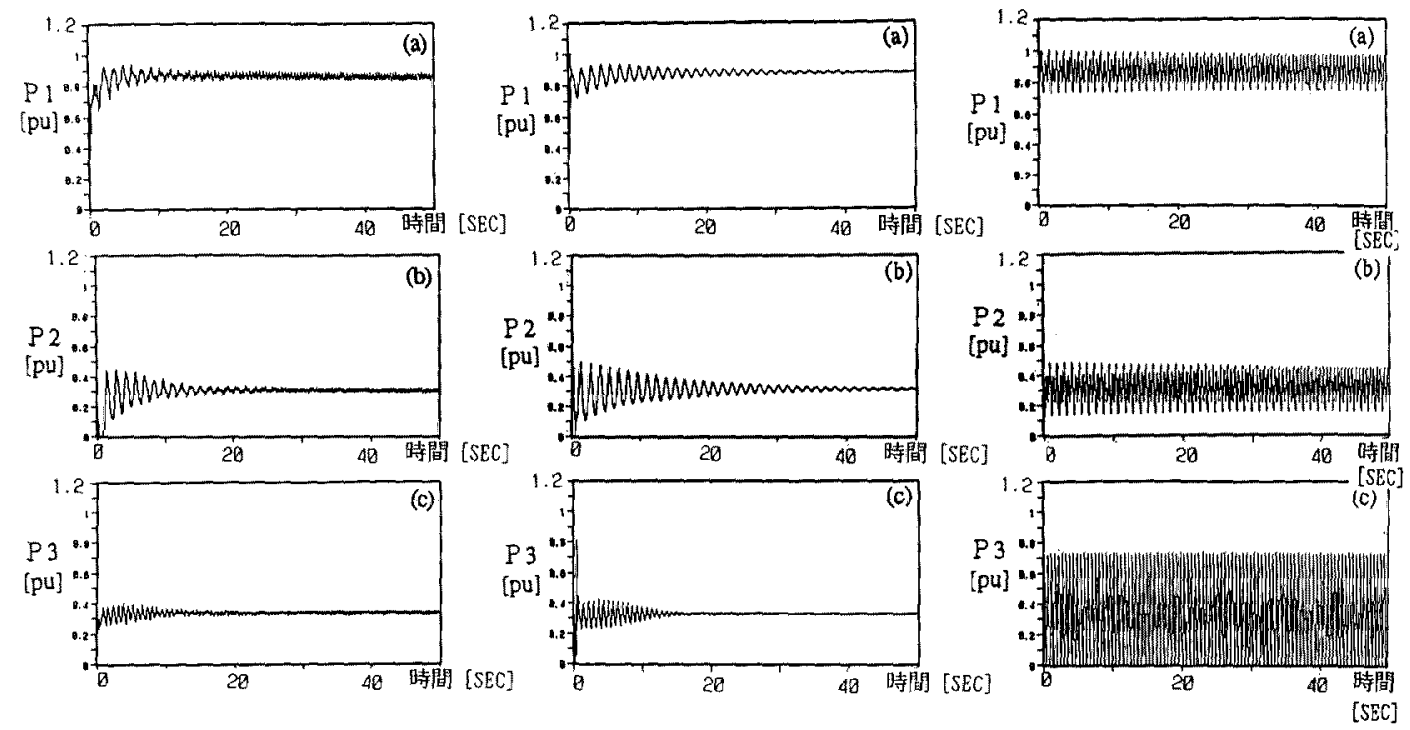

(1) APSA

(II) Parkモデル

Runge-kutta 使用 $\Delta t=0.3 \mathrm{~ms}$

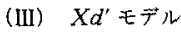

Runge-kutta 使用 $\Delta t=0.3 \mathrm{~ms}$

図 4 Case 1 の有効電力の時間軸波形（事故時間：0.208 s, 制動巻線：なし)

Fig. 4. Time domain waveforms of real power in Case 1.
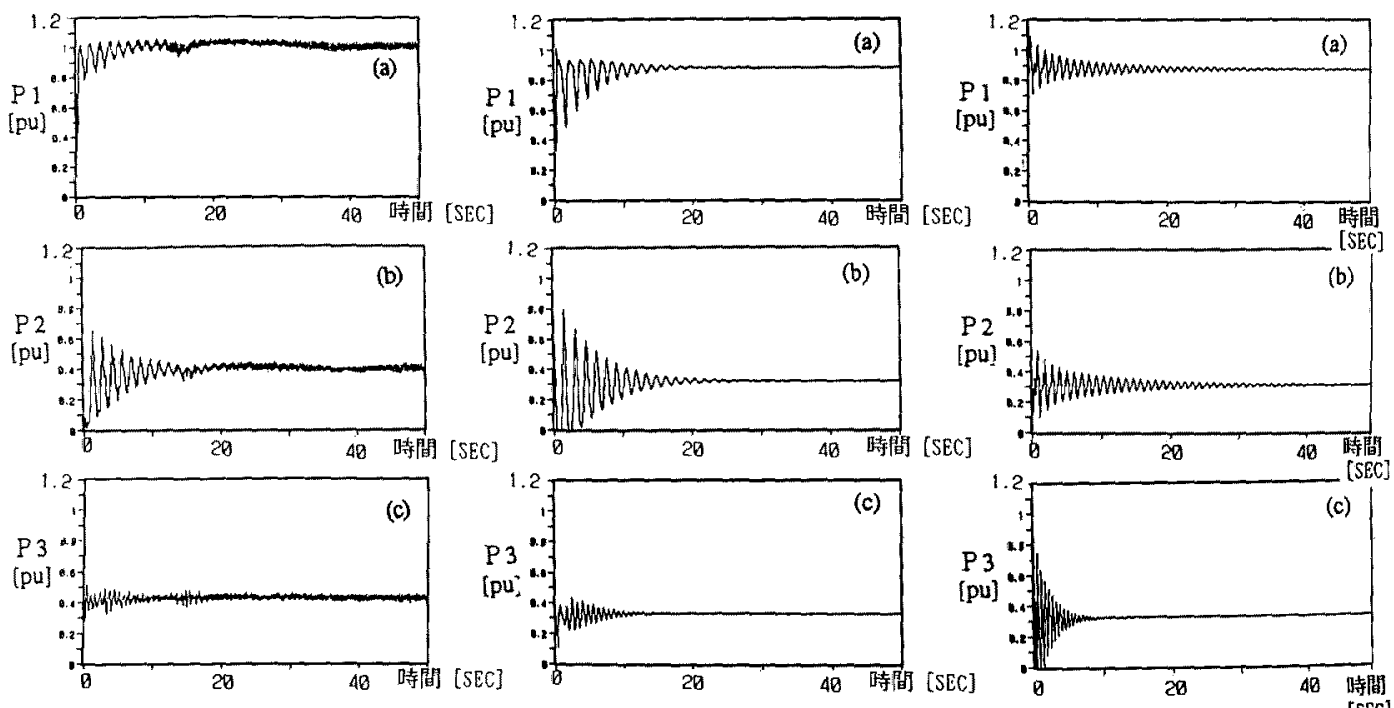

(II) Park モ゙ル

Runge-kutta 使用 $\Delta t=0.3 \mathrm{~ms}$
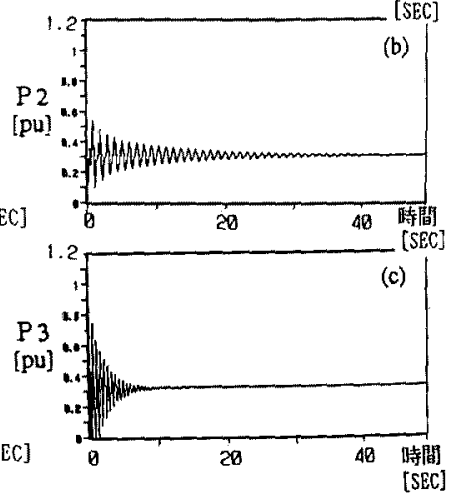

(I) APSA

(III) Xd'モデル

Runge-kutta 使用 $\Delta t=0.3 \mathrm{~ms}$

図 5 Case 2 の有効電力の時間軸波形（事故時間：0.333 $\mathrm{s}$, 制動巻線：有)

Fig. 5. Time domain waveforms of real power in Case 2.

の波形を考える。

図6 抢よび図7 (c)，(d)は，をれでれの(a), (b)図に示されるエンベロープの全幅を読み取り，そ の常用対数を 0.5 秒ごとに 10 秒までプロットしたも
のである。

Case 1(制動巻線なし)について考えると，図6 (c)，(d)より，隇衰定数が 4 秒近辺を境に性質が変 化している様子がわかる。つまり，モードNo.2は4 


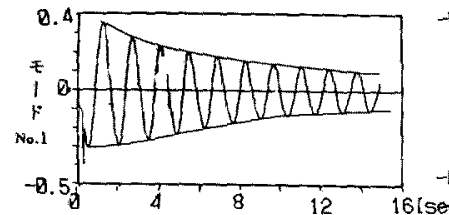

(a) $\forall-ト N$ No.10エンベローフ

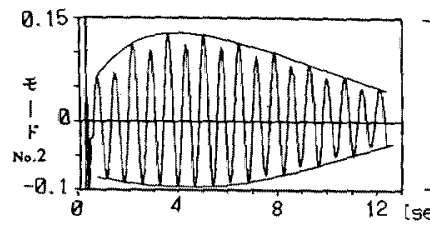

(b) モードNo.2 ゚エンバローナ゙

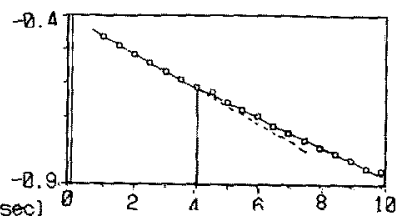

(c) $₹-F N_{0} 10$ 隇衰 $[\sec ]$

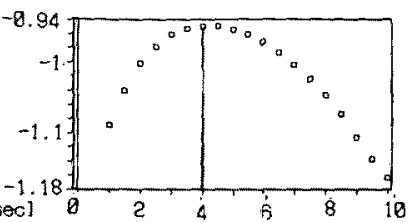

(d) E-F゙No.20減喜 [sec]

図 6 減衰定数の変化 Case 1(Park)

Fig. 6. Change in attenuation constant Case 1 (Park).
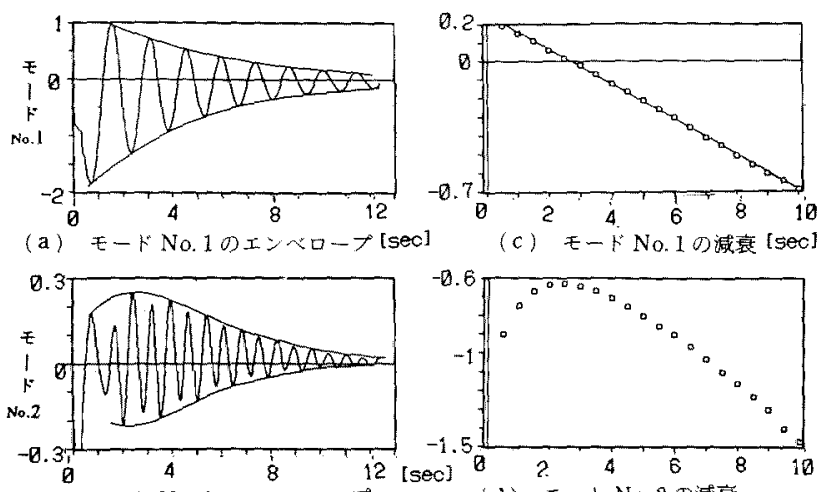

(c) モ一トNo.10隇衰 [sec]

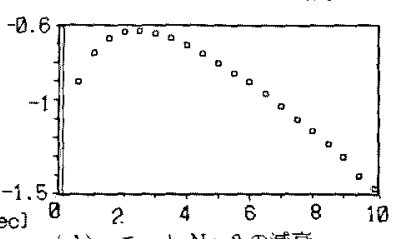

(d) $z-N$ No.20隇衰 [sec]

図 7 減衰定数の変化 Case 2(Park)

Fig. 7. Change in attenuation constant Case 2 (Park).

秒以前は傾きは正でエネルギ一が増大に向かっている が，その後負に変化し減少方向になっている。一方， モードNo.1は，滅衰定数が負から正へと変化すれ ば，モードNo.2からのエネルギーの授受といえる が，実際は，4秒以後の減衰定数が正まで変化せずに 若干小さくなっている。これは，系統のダンピングに よりその変化が弱まったものと考光ると，4秒の時点 でそのエネルギーが逆方向に移動しているものと考光 られる。

一方，図７に示すCase 2(制動巻線あり)では，モ ードNo.1のエンベロープの隇衰定数に注変化が見ら れず、エネルギー授受は起こっていないとものと思わ れる。

両ケースの判定結果より, Case 1 は制動巻線なし のケースであるため，ダンピングが比較的小さく，内 部共振が顕在化しやすいと考えられる(22)。更に, 計 測から明らかではないが，より大きな外乱を与えた場
合に壮制動巻線ありの場合にも内部共振が発生するの ではないかと思われる。

〈4・4〉 スペクトル解析による分析 ディジタル 計算結果に対して内部型パラメー夕共振発生の有無 は，ダンピングが比較的小さい場合にはモード波形を 計算し，その形状を直接観察することで判定でき，更 にダンピングが比較的大きく，エネルギー授受がマス クされやすい場合でも，モード波形の隇衰定数の変化 によって判定できる。しかし，モード波形に必要な固 有値解析は，正確な数式モデルを前提とするため， APSAの計測波形に対しては，いずれの判定方法も 適用することはできない。

そこで本節では，スペクトル解析による判定を試み た。移動FFTによる解析では線形の減衰時定数抢よ び固有周波数に対する判定に注有効であるが，パラメ 一夕共振の確認には必ずしも良好な結果を与えておら ず，非線形現象を含んだ波形の解析が必要となる。こ 

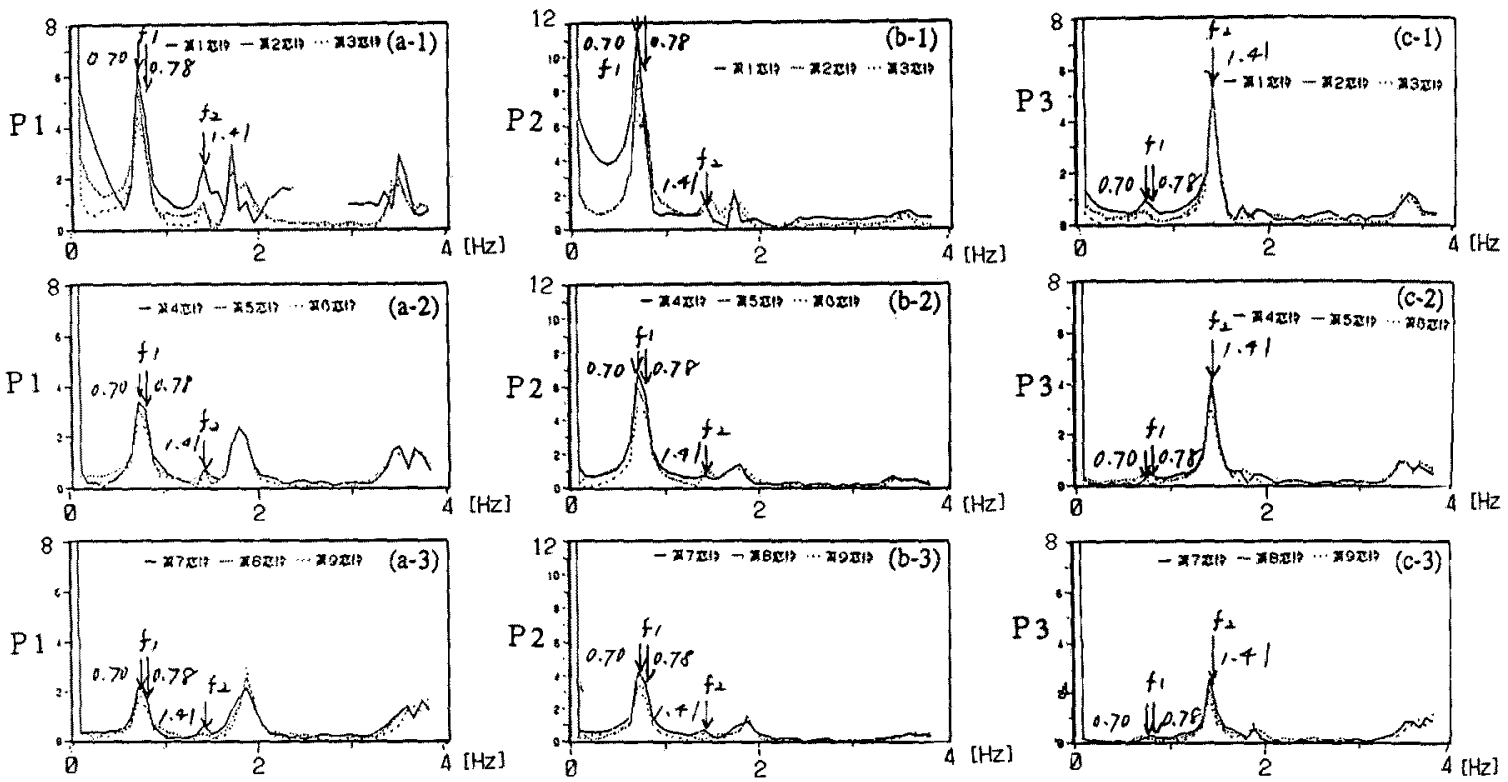

図 8 FFTによるスペクトル密度 Case 1(APSA)

Fig. 8. Spectral density computed by FFT Case 1 (APSA).

表 5 固有周波数の比較

Table 5. Comparison of mode frequencies.

\begin{tabular}{|c|c|c|c|}
\hline Case No. & モデル & $\mathrm{f} 1[\mathrm{~Hz}]$ & $\mathrm{f}_{2}[\mathrm{~Hz}]$ \\
\hline \multirow{3}{*}{ Case 1 } & APSA & $0.70 \sim 0.78$ & 1.41 \\
\cline { 2 - 4 } & Parkモデル & 0.73 & 1.40 \\
\cline { 2 - 4 } & Xd'モテルル & 0.94 & 1.88 \\
\hline \multirow{3}{*}{ Case 2 } & APSA & 0.78 & 1.48 \\
\cline { 2 - 4 } & Parkモデル & 0.73 & 1.41 \\
\cline { 2 - 4 } & Xd'モテル & 0.94 & 1.88 \\
\hline
\end{tabular}

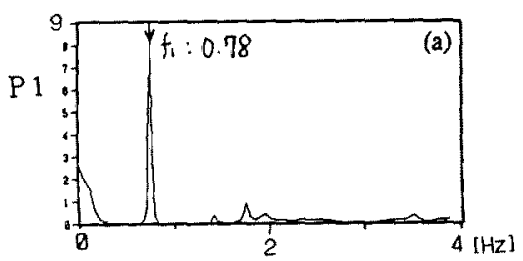

表 6 減衰定数の比較

Table 6. Comparison of attenuation constants.

\begin{tabular}{|c|c|c|c|}
\hline$r-3$ & E-F周波数 & 減亲定数の平均値 & 固有俌実部 \\
\hline \multirow{3}{*}{ Case 1} & Pान 11 & -0.155 & \multirow[b]{2}{*}{-0.0712} \\
\hline & $\mathrm{P} 2 \sigma \mathrm{f} 1$ & -0.155 & \\
\hline & P3のf 2 & -0.171 & -0.1662 \\
\hline \multirow{3}{*}{ Case2 } & P10f1 & -0.179 & \multirow{3}{*}{-0.1985} \\
\hline & P20 1 & -0.180 & \\
\hline & P3कf & -0.294 & \\
\hline
\end{tabular}

単位 $[1 / \mathrm{sec}]$

図 9 MEMによるスペクトル密度 Case 1(APSA)

Fig. 9. Spectral density computed by MEM Case 1 (APSA).

のため，更にMEMによるスペクトル分布形状を調 べることでその特徵を把握した。

（1）移動FFTによる解析 移動FFTの計算 結果の一例を図 8 に示す。また，これから得られた APSAの固有周波数とディジタル計算の固有值を比 較したものが表 5 である。これを見ると，Parkモデ ルの計算結果はAPSAの固有周波数とかなり近接し

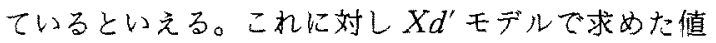

は大きく離れており，Parkモデルの有用性が確認さ れる。

次に，各モードの周波数成分の1秒ごとの減哀定数 を平均したものを表 6 に示す。同表には比較のために それぞれのモードに対応するPark モデルの固有值実 部も示した。これより次のことがいえる。

(i) 隇衰定数と固有値を比較するとCase 1 では

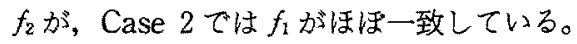


(ii）両ケースとも減衰定数からモードNo.10ほ うが，モードNo.2より減衰が速いことがわかるが， これは固有値の与える情報と一致する。

(iii) $P_{1}, P_{2}$ に含まれる周波数成分 $f_{1}$ の減定数の 平均值について, Case 1 は両者とも -0.155 , Case 2 はー0.179と一0.18と各々のCaseで，相等しい。

以上のことより，移動 FFTによる解析結果は固有 値との比較という観点から，振動モードの振舞いの線 形な部分の特徵を十分表しているといえる。

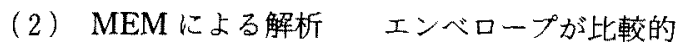
低い周波数 $f_{E N}$ で振動する場合，一般にスペタトル密 度の山は振動周波数 $f$ から士 $f_{E N}$ だけずれたところに 現れるが，FFTではこのような特徽を抽出すること はできなかった。FFTに比べより優れた分解能を有 する，MEMによって求めたスペクトル密度分布を図 9 に示す。(b)，(c)図ではモード周波数 $f_{1}$ 抢よび $f_{2}$ の付近に二つの山が見られる。(c)図から概算さ れる $f_{E N}$ は,この二つの山の周波数差より $f_{E N}=$ $(1.482-1.365) / 2 \fallingdotseq 0.058 \mathrm{~Hz}$ であり, 周期は $1 / 0.058$ $\fallingdotseq 17.3 \mathrm{~s}$ となる。このことは Case 1 のードNo.2 に17.3/2 $98.7 \mathrm{~s}$ のビート現象を指摘することがで きこれは図 4 (I)-(c)のP P のビート現象が約 12 秒であることと比較的よく一致するといえる。

以上の分析結果を以下にまとめる。

(i) Parkモデルを用いたディジタル計算結果は APSA との比較に扮いて時間軸波形がよく一致した。 また，固有值の与文る知見はAPSAの振動モードの 振舞いと比較的よく一致した。

(ii）モード波形の減京定数の変化に着目した解析 によって, 内部型パラメー夕共振のエネルギー授受発 生の有無に関する情報がある程度得られることがわか つた。

(iii） MEMによるスペクトル解析を用い，その高 い周波数分解能に上り内部型パラメータ共振のビート 現象を近接した周波数としてとらえた。

本章の分析において内部型パラメータ共振のエネル ギー授受の現象の性質は影著には現れなかったが，こ の理由として次のことが考えられる。すなるち，本試 験で取り上げた潮流は、発電機の出力配行を，スペク トル解析を行かなくても特定の発電機の出力端で比較 的純粋な振動モードが観測できるよう調整したもので あった。これは，いわばモードNo.1とモードNo.2 の相互作用を蹯にする操作であったのではないかと考 えられる。つまり，この操作が振動モード間のエネル ギー授受として特徽づけられる内部型パラメータ共振 の発生を困難にさせた可能性を指摘する。

\section{5.まとぬ}

本論文では, 内部型パラメー夕共振约対する現象波 形の份析手法とその現象確認の手法を確立するため, APSAによるシミュレーションとディジタル計算と の比較を行い, エネルギー授受の有無について検討し た。

今回得た解析技術により，試験を行う前にPark モ デルの固有值や時間軸の生波形およびモード領域の波 形，更にはスペクトル解析の波形まで検討することが でき，内部共振の起こりやすい条件を事前に各方面か ら探索することが可能となった。

また本論文では，試験によって得た波形に対する解 釈の方法について提案し,内部型パラメ一夕共振の発 生を確認した。

本研究を実施するにあたり，多くの方々から多大の 御支援を賜った。就中, 関西電力(株)総合技術研究所 森岡靖夫, 加藤正直両副主任研究員, 関西計器工業 (株) 西时周治, 中野武誠画氏はAPSAの運転管理, 計測を全面的に担当された。他方, 試験データの整 理・解析に努力を傾注した早稲田大学田村研究室大学 院生本吉高行 [現, 東京電力(株)], 緒方隆雄(現, 東 京がス(株)], 梅田信雄, 坂下健二, 斎藤 寛, 張 徳評 （以上，修士 2 年）の六氏に対し感謝の意を表したい。最 後に，大規模アナログ型電力系統シミュレータ APSA 学活用する機会を抢与え下さつた関西電力(株) 総合 技術研究所所 和廣所長ならびに藤井正規副所長に 哚甚なる謝意を表する。（平成 4 年 12 月 7 日受付)

\section{文献}

（1）田村：「電力系統の翡線形現象について」，計溉と制御，29， 251 (平 2-3)

(2) Y. Tamura, N. Yorino, et al: "On the Possibility of Parametric Resonance in Power Systems-A New Concept of Power System Stability", Proc. PSCC-Vill, Helsinki (1984)

（3）沖, 他：「大規模アナロク電力系統ジミレータの開発〈そ

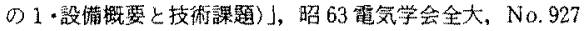

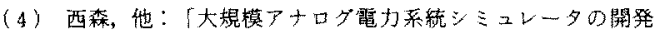
(その2・発電機.ニット) b, 昭 63 同上, No. 928

(5) 福本, 他：「大規模アナログ電力系統シミュレー夕の開発 （その3・急荷ュニット），昭 63 同上，No. 929

(6) 広部, 他：「大規模アナログ電力系統シミュレータの開発 (その 4 ・自動結線システム)」, 昭 63 同上, No. 930

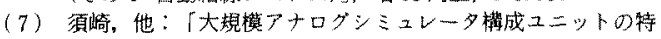
性」, 電気学会電力技湖研資, $\mathrm{PE}-89-116$ (平元)

（8）森罚，他：「大規模アナログシミュレー夕臬用システム」, 同上, PE-89-117 (平元)

（9）加藤：「バラメー夕共振現象との遭遇」，R \& D News Kansai (平 3-4)

(10) Y. Tamura \& N. Yorino: "On Quantitative Analysis of Nonlinear Long-Term Phenomena in Power Systems from Parametric Resonance Viewpoint", IASTED, Montana (1986) 
（11）餘利野・日村，他：「電力系統におけるパラメー夕共振につ いて」, 筐学論 B, 105, 805 (昭 60-10)

（12）餘利野・田村：「電力系統におけるパラメー夕共振の分類と 特徵抽出」, 同上 B, 106, 503 (昭 61-6)

(13) A. H. Neyfeh \& D. T. Mook: Nonlinear Oscillations (1979) John Wiley \& Sons

（14）斎藤・田村, 他：「電力系統における内部型パラメー夕共振 の高次近似の必要性」, 平 4 電気学会全大, No. 1035

（15）須崎・土井・広部：「高性能系統解析試験蒋置の特性試験結果 一実系統試験との対比結果一 $\}$, 電気学会電力技術研資, $\mathrm{PE}$ $-90-37$ (平 2)

（16）森岡・吉田・斎川：「高性能系統解析試験装置の特性試験結果 一モデル系統による雨圧問題解析一」, 電力技術研資, $\mathrm{PE}$ 90-37 (平 2)

（17）土井・森岡・須崎，他：「高性能系統解析試駼装置の特性試験 結果一TAGEC 機能の検証結果一」, 同上, PE-90-39 (平 2)

(18) P.M. Anderson \& A. A. Fouad: Power System Control and Stability (1977) Iowa State University

（19）日野：スペクトル解析（昭 52）朝倉書店

(20) J. P. Burg: "Maximum Entropy Spectral analysis", 37tn Annual International Meeting, Soc. of Explor. Geophys., Oklahoma (1967)

（21）内田, 他：「長距離串型系統の不安定動摇現象とその対策」, 電中研報告, T88001（昭 63）

（22）餘利野・时村, 他：「電力系統における内部型パラメー夕共 振とその解析手法について」, 電学論 $\mathrm{B}, 108,328$ (昭 63-7)

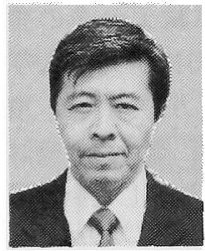

\section{富山勝 幸（正員）}

昭和 20 年 3 月 25 日生。 38 年 3 月淀 川工業高校電気学科卒業。同年 4 月関西 電力(株) 入社。 46 年 3 月姫路工業大学 電気工学科卒業。現在, 総合技術研究 員。主として, 電力系統の安定度関係の研究に従事。

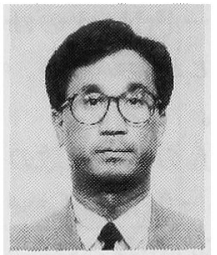

\section{中 西 要 祐（正員）}

昭和 30 年 1 月 6 日生。 55 年 3 月早稲 田大学大学院修士卒業。同年 4 月富士電 機(株)入社。現在，富士電機総合研究所 主査。主として, 電圧不安定性現象の解 析, シミュレーション手法の研究に従事。平成 3 年 IEEE 表彰 (電力系統教育委員会)。IEEE 会員。

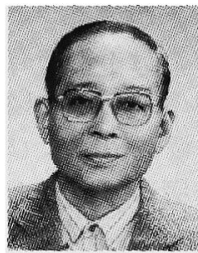

\section{田村 康 男 (正員)}

昭和 6 年 9 月 21 日生。 28 年早稲田大 学理工学部電気工学科卒業。30 年同大 学理工学部助手嘱任。32〜33 年アメリ 力の Univ. of Michigan 交換研究員。44 年早稲田大学理工学部教授嘱任, 現在に至る。工学博士。 $46 \sim 47$ 年シドニ一大学交換教授。 45 年, 48 年電気学会論 文賞。48 54 年 CIGRE SC- 32 国内委員長。 59 年中国武 漢水利電力学院名誉教授。 $59 \sim 60$ 年電気学会東京支部長。 60 年ベルギー Liege 大学国際学術賞 (パラメータ共振), 61 年電気学会電力賞受賞。 $62 \sim 64$ 年電気学会副会長。平 成 2 年 IEEE tutorial コース（電圧安定性）講師。3 年 IEEE 表彰（電力系統教育委員会）。IEEE Fellow。 